\title{
Contribution of Production Unit Experience, Soft Skill, and On The Job Training to Student's Competency and its Effect to The Work Readiness
}

\author{
Dyah Ayu Pradnya Paramitha ${ }^{1 *}$ Krismadinata $^{2}$ dan Nizwardi Jalinus ${ }^{3}$ \\ ${ }^{1}$ Culinary Management Study Program, Batam Tourism Polytechnic \\ ${ }^{2}$ Department of Electrical Engineering, Faculty of Engineering, State University of Padang \\ ${ }^{3}$ Postgraduate Program, Faculty of Engineering, State University of Padang \\ *Corresponding author, e-mail: dyah@btp.ac.id
}

\begin{abstract}
The goal of this research was to know contribution between exogenous variable to the endogenous variable. Exogenous variable was practical of production unit $\left(X_{1}\right)$, soft skill $\left(X_{2}\right)$, and on the job training $\left(X_{3}\right)$, whereas endogenous variable was student's competency $(\mathrm{Y})$ and work readiness $(\mathrm{Z})$. This research used quantitative approach with survey method. The research population was students in the Culinary Study Program at Batam Tourism Polytechnic. Sample in this research was 122 respondents that determined by using proportional random sampling technique. Data collection technique used questionnaire and documentation, data analysis technique that used in this research was path analysis. Test in the path analysis was divided into two groups, simultaneously and individually. The research result showed that there was significant contribution between practical experience of production unit, soft skill, and on the job training to the student competence, and significant contribution between practical experience of production unit, soft skill, on the job training, and student competence to the work readiness.
\end{abstract}

Keywords : Production Unit Experience, Soft Skill, On the Job Training, Student Competence,

\section{INTRODUCTION}

Life continuity of a nation is heavily depend on the owned human resource quality. One component that needed to create qualified human resource is education. Education is the right facility to obtain knowledge, attitude, life skill values, and skill that needed in the life. Student that been obtained knowledge and skill expected to have work readiness [9].

Vocational education is demanded to be able to produce graduates with competence as what been expected by the world of work, which is competence that suitable with the job field, having adaptation and high competitiveness. Although Vocational education is directed to create the student to be ready in working, however it still not implemented well. Based on the result of survey that been conducted by Central Bureau of Statistics which next managed by Data and Employment Information Center on August 2018, students who graduate from Vocational High School in Indonesia place the highest position in open unemployment level seen from education with the score up to $11.24 \%$ or $1,332,186$ people. Absolutely, that still becomes a problem that need to be solved. Explained the high number of unemployment in Indonesia caused by competence that owned by Human Resource of Indonesia still low. Moreover, in 2015 will be opened by ASEAN free market, thus it will cause in mobility of employment among countries in ASEAN which can't be prevented anymore. Then, it will create tight competition especially competition in getting a job [14].

The improvement of competitiveness can be started from qualified Human Resource preparation which becomes main factor in facing the competition, to cope with the problem, then government needs to make policy with the goal to improve education quality on Vocational Education. To produce employment suitable with the needs of the world of work, then it needs Polytechnic graduates who have good competence and work readiness. 
According to [14], work readiness seen as physical, mental, and vocational source preparation to enter to the competitive job field. Work readiness is important to be owned by Polytechnic student because the student is society expectation to be a graduate that has competence as with the skill field. Based on the review above, it can be stated that work readiness is maturity condition to work and face the competitive work challenge. Polytechnic graduates that still not ready to work can be caused by not enough competence to be accepted in the world of work.

Employment competence that needed by Business or Industrial World is Human resource that have competence as with the job field. By the used competence then one can do certain task which based on knowledge, skill, and attitude. To assure owned competence of Batam Tourism Polytechnic (BTP) graduates then starting from academic year 2018/2019 National Education Department had implemented Vocational Competence Test. The question of Vocational Competence Test arranged and established by BNSP (National Standard Board of Education) in PP Number 23 Year of 2004. Student that stated as graduate will get certificate which published by certification institution, company/industry, education and training institution which has credibility in the field or education and training institution which given by authority by certification institution. Certificate for Vocational Competence Test can improve the trust from side of Business/Industrial World to the BTP graduates. Thus, by following Vocational Competence Test expected that student has good work readiness.

The achievement of student competence also can be affected by practical experience of production unit, soft skill ability, and implementation of industrial work practice. Stated that mastering to the learning material without counter of adequate practical ability will be useless [14]. Knowledge that obtained is not enough for student to go to the world of work. BTP graduates expected to have qualification as with standardization of the world of work. [7] argued that knowledge that obtained from formal education is not guarantee to get a job. Unallocated job vacancy generally caused by low work readiness and less skill. Knowledge that obtained from vocational subject is not enough as provision to enter the world of work, thus it needs skill support from production unit practice and industrial work practice and also student soft skill.
Batam Tourism Polytechnic in 2016, in its policy gives program facility to develop program of school production unit, with one of its objective is making Polytechnic as education and training practical activity place which oriented to the world of work. According to [5] what been intended by production unit in school is a process of enterprise activity that conducted in school, profit oriented with the doer of school population to optimize school and environment source, and many enterprise units as with the ability which managed professionally.

The implementation of on the job training is standardized in the Decision of Education and Culture Minister of Indonesia Republic NO. 323/U/1997 about the implementation of dual system in Vocational Education. On the job training is part of dual system education which is innovation of Vocational education where the student doing apprenticeship in industry that relevant with the skill competence for certain time. Education model of dual system is quite effective system to educate and prepare a student to go in-depth and master complex skill which impossible or never conducted in school. Industrial work practice will give experience, skill, and description about real condition of Business/Industrial World, thus student knows what is necessary by the world of work that finally will encourage student to prepare their self in entering the world of work.

Soft skill mastering for Culinary student is important and very needed to work. This ability is key that make the student able to work together as reliable team, communicated effectively to build performance, solving work problem quickly, improving work productivity based quality and superiority, and developing effective and efficient thinking pattern. According to [1] the success of graduates in career determined by two factors, knowledge and technology and soft skill. Knowledge and technology mastering necessary as representation of skill mastering, and soft skill mastering is needed in order to go fast in success in the world of work competition.

The research about competence achievement and work readiness which affected by practical activity of production unit, student soft skill, and the experience of industrial work practice was conducted in Batam Tourism Polytechnic for Culinary skill competence. There were many consideration to conduct research in those schools. According to the interview with Director and Vice Director at Batam Tourism Polytechnic that there are many, especially for Batam Tourism 
Polytechnic student that newly graduate and not confuse to continue the study or got to work directly. If they go to work, students feel that they have enough experience and ability to enter the world of work especially Culinary field, they are have good self-confidence if compared by professional worker. The study of [10] concluded that work readiness of Vocational Educatonal student to work in industry placed in the low level, seen from talent, learning process to productive subject, and competence.

Production Unit Practice: Vocational education through [5], in its policy gives program facility to develop program of school production unit, with one of its objective is making Vocational as education and training practical activity place which oriented to the world of work. With assumption that Vocational High School as formal education institution that conduct learning process based the world of work, it is very possible to result product and service that feasible to be sold and able to compete in work market. Therefore, vocational education really needs to create and develop real work learning condition, in this case by doing production and service unit practice around the school especially vocational education.

Practical activity in the school production unit more emphasizes on student learning process through direct practical activity in real work (learning by doing) at learning activity scope in school. During the activity of production unit practice, student will achieve skill, coaching, and much training in production unit management. It is realized in job description such as giving service to consumer, doing production, marketing, and financial management from enterprise of production unit management.

Goal of Production Unit Practice: Based on guidelines of implementation management of production unit, the implementation of production unit Vocational Education School has many objectives as follow: (a) Giving opportunity to student and teacher in conducting practice which oriented to the market around the school, (b) Growing and developing entrepreneurship spirit of teacher and student in the Vocational Education, (c) Improving work competence of teacher and student, (d) Assisting funding for maintenance, facility addition, and other education operational cost, (e) Training to be brave to take risk with proper calculation, (f) Improving creativity and innovation in student, teacher, and school management environment.
Soft Skill: Soft skill basically one's skill in relation with other (interpersonal skill) and skill in managing themselves (intrapersonal skill) which able to develop performance maximally. In other word, soft skill is in and out of self quality. Soft skill also includes definition of non-technical skill, skill which can affect academic ability and ability which must be owned by everyone in any profession. Intrapersonal skill is ability to recognize and control our self. This competence consists of: understanding about success, self evaluation, self image, gold setting, self motivation, emotion control, and self-confidence. Interpersonal skill is ability to communicate and interacted with others. This competence consists of: empathy communication, assertive communication, developing relationship in teamwork, self marketing, and developing positive relation [18].

The Advantage of Soft Skill for Graduates: National Department of Indonesia Republic in 2009 stated that someone's success in education $85 \%$ determined by soft skill and the remaining is $15 \%$ determined by hard skill. Soft skill is heavily needed in the use of plan and job seeking process and also the success in career. It identifies that soft skill determine the speed of graduates in getting a job, beside the hard skill [16]. Clearly it is pointed that soft skill role is heavily needed to be able to compete in getting a job, career, and to build an enterprise. Basically, soft skill has many advantages such as career development and professional ethics. From organizational side, soft skill gives effect to the totally management quality, institutional effectiveness, and innovation synergy. The essence of soft skill is opportunity. The graduates need soft skill to open and use the opportunity [12].

The Experience of Industrial Work Practice: Industrial Practice is one stage of professional preparation where a student who almost finishes the study formally works in the field with supervision of competent administrator in the certain period, which aims to develop ability in doing responsibility in the field [6]. Laws No. 20 Year of 2003 stated that basically the implementation of industrial work practice to the Vocational High School conducted for 3 months. The extended time is allowed for 3,5 months to 4 months, and it is possible with Decision Letter of Education and Culture Minister and suitable with Government Rule No.29 Year of 1990. According to the implementation of industrial work practice in Vocational Education presently can be started 
in semester $3^{\text {rd }}$ and semester $8^{\text {th }}$ with time period three to six months in the effective time of work.

Vocational Competence Test: Skill acknowledgement is conducted through process of skill testing system which refers to skill standard which prevailed and acknowledged in the work field. Through the implementation of Vocational Competence Test is expected to guarantee the implementation of competence based assessment that more comply to principle and in turn it can encourage learning process based on competence/production. Vocational Competence Test is evaluation process to a number of competence that been learned by student, thus the implementation of Vocational Competence Test is an assessment which refers to the certain size to state a student been competent or not competent yet. In the draft of Technical Guidelines of Vocational Competence Test Implementation for Culinary Mangement Study Program it was explained that assessment of vocational skill competence subject basically is assessment that conducted thoroughly and as a whole which includes attitude, knowledge, and skill aspect. It is suitable with alteration element that occurred in curriculum BTP, which is in the Graduates Competence Standard.

Work Readiness: Work readiness is main capital for student to do many jobs in order to get maximal result. Work readiness means as a condition which shows the harmony between physical, mental, and experience maturity thus individu has ability to do certain activity related with job or activity. Work readiness is heavily needed because by good work readiness it will be created tough and qualified employment then it can compete in the world of work. Characteristic of student that been owned work readiness as follow: (a) having logical and objective consideration, (b) focus to the target, (c) risk taker, (d) having ability to adapt with environment, having critical attitude, (e) having braveness to accept responsibility from every job, (f) having ambition to be better, (g) trying to follow the development of skill field, and (h) having ability to cooperate with other [17].

\section{RESEARCH METHOD}

This research design used quantitative approach with survey method

Research Subject: The research subject was students in BTP, Culinary Study Program with total population for 122 respondents that determined by using proportional random sampling technique

Research Instrument: Instrument that used was questionnaire which comprises of statements and developed from indicator based on theory that relevant with each research variable, measured by using Likert scale.

Data Collection Technique: Data practical activity of production unit, soft skill, on the job training, and work readiness taken by using questionnaire, whereas data of student competence taken by using documentation of student score.

Data Analysis: Data analysis that used in this research is path analysis using SPSS for Windows Version 25. Data test in the path analysis was divided into two, simultaneously and individually.

\section{RESEARCH METHOD}

This research design used quantitative approach with survey method

Research Subject: The research subject was students in BTP, Culinary Study Program with total population for 122 respondents that determined by using proportional random sampling technique

Research Instrument: Instrument that used was questionnaire which comprises of statements and developed from indicator based on theory that relevant with each research variable, measured by using Likert scale.

Data Collection Technique: Data practical activity of production unit, soft skill, on the job training, and work readiness taken by using questionnaire, whereas data of student competence taken by using documentation of student score.

Data Analysis: Data analysis that used in this research is path analysis using SPSS for Windows Version 25. Data test in the path analysis was divided into two, simultaneously and individually.

\section{RESEARCH RESULTS \& DISCUSSION}

\section{Result}

Test of Sub-Structure 1

This test included simultaneously test to know contribution from practical activity of production unit, soft skill, and the experience of 
industrial work practice to the student competence. Besides that, it also tested individually among each independent variable (X) to student competence variable (Y).

Table 1. Counting Result Coefficient Correlation and Regression Sub-Structure 1

\begin{tabular}{|c|c|c|c|c|c|}
\hline \multicolumn{6}{|c|}{ Correlations } \\
\hline & & $\mathrm{X} 1$ & $\mathrm{X} 2$ & $\mathrm{X} 3$ & $\mathrm{Y}$ \\
\hline \multirow[t]{3}{*}{$\mathrm{X} 1$} & Pearson Correlation & 1 & $.976^{* *}$ & $.979^{* *}$ & $991^{* *}$ \\
\hline & Sig. (2-tailed) & & .000 & .000 & .000 \\
\hline & $\mathrm{N}$ & 122 & 122 & 122 & 122 \\
\hline \multirow[t]{3}{*}{$\mathrm{X} 2$} & Pearson Correlation & $.976^{* *}$ & 1 & $.948^{* *}$ & $.982^{* *}$ \\
\hline & Sig. (2-tailed) & .000 & & .000 & .000 \\
\hline & $\mathrm{N}$ & 122 & 122 & 122 & 122 \\
\hline \multirow[t]{3}{*}{ X3 } & Pearson Correlation & $.979^{* *}$ & $.948^{* *}$ & 1 & $.978^{* *}$ \\
\hline & Sig. (2-tailed) & .000 & .000 & & .000 \\
\hline & $\mathrm{N}$ & 122 & 122 & 122 & 122 \\
\hline \multirow[t]{3}{*}{$\mathrm{Y}$} & Pearson Correlation & $.991^{* *}$ & $.982^{* *}$ & $.978^{* *}$ & 1 \\
\hline & Sig. (2-tailed) & .000 & .000 & .000 & \\
\hline & $\mathrm{N}$ & 122 & 122 & 122 & 122 \\
\hline
\end{tabular}

**. Correlation is significant at the 0.01 level (2-tailed).

Table 2. Summary Sub-Structure 1

\begin{tabular}{rrrrrr}
\hline Model & $\mathrm{R}$ & R Square & Adjusted R Square & $\begin{array}{l}\text { Std. Error of the } \\
\text { Estimate }\end{array}$ & $\begin{array}{c}\text { Durbin- } \\
\text { Watson }\end{array}$ \\
\hline 1 & & .990 & .989 & .41622 & 1.998 \\
\hline
\end{tabular}

a. Predictors: (Constant), X3, X2, X1

b. Dependent Variable: Y

Table 3. Anova Sub-Structure 1

\begin{tabular}{llrrrrr}
\hline \multicolumn{7}{c}{ ANOVA $^{\mathbf{b}}$} \\
\hline Model & & Sum of Squares & df & Mean Square & \multicolumn{1}{c}{ F } & \multicolumn{1}{c}{ Sig. } \\
\hline 1 & Regression & 1935.173 & 3 & 645.058 & 3723.592 & $.000^{\text {a }}$ \\
& Residual & 20.442 & 118 & .173 & & \\
& Total & 1955.615 & 121 & & & \\
\hline
\end{tabular}

a. Predictors: (Constant), X3, X2, X1

b. Dependent Variable: Y

Table 4. Coefficient Sub-Structure 1

\begin{tabular}{|c|c|c|c|c|c|c|c|}
\hline & \multicolumn{6}{|c|}{ Coefficients $^{a}$} & \\
\hline \multirow[t]{2}{*}{ Model } & \multicolumn{2}{|c|}{$\begin{array}{l}\text { Unstandardized } \\
\text { Coefficients }\end{array}$} & \multirow{2}{*}{$\begin{array}{c}\text { Standardized } \\
\text { Coefficients } \\
\text { Beta }\end{array}$} & \multirow[b]{2}{*}{$\mathrm{T}$} & \multirow[b]{2}{*}{ Sig. } & \multicolumn{2}{|c|}{ Collinearity Statistics } \\
\hline & $\mathrm{B}$ & Std. Error & & & & Tolerance & VIF \\
\hline 1 (Cons & -8.306 & 1.994 & & -4.166 & .000 & & \\
\hline $\mathrm{X} 1$ & .379 & .068 & 380 & 5.599 & .000 & .019 & 51.953 \\
\hline $\mathrm{X} 2$ & .348 & .041 & .365 & 8.401 & .000 & .047 & 21.333 \\
\hline X3 & .269 & .049 & .260 & 5.542 & .000 & .040 & 24.85 \\
\hline
\end{tabular}

a. Dependent Variable: Y 
Table 1 showed that among variable in sub-structure 1 had interrelation or correlated each other. In the Table 2 could be seen that determinant coefficient $R_{\text {square }}$ or $R^{2}{ }_{y \times 1 \times 2 \times 3}=0.990$ $=99 \%$ and the effect of other variable $=1-0.990$ $=1 \%$. Table 3 was obtained $\mathrm{F}$ value for 3723.592 with probability value Sig. $=0.000$, because Sig. $<0.05$ then Ha was accepted and Ho rejected. It means that there was significant contribution between practical activity of production unit, soft skill, and on the job training to the student Skill Competence of Culinary, thus individually test could be conducted.

\section{Individual Test of sub-structure-1}

Principle of this significance test was conducted by comparing probability value and $\mathrm{Sig}$ value (sig. < 0.05). Table 4 showed the result of path coefficient $\rho_{\mathrm{yx} 1}=0,380$ sig. $=0,000, \rho_{\mathrm{yx} 2}=0,365$ sig. $=0,000, \rho_{\mathrm{yx} 3}=0,260$ sig. $=0,000$, which means all independent variable (X) had contribution to dependent variable (Y).

\section{Test of Sub-Structure-2}

This test included simultaneously test to know contribution from practical activity of production unit, soft skill, and the experience of industrial work practice to the student competence. Besides that, it also tested individually among each independent variable $(\mathrm{X})$ and variable $(\mathrm{Y})$ to work readiness variable $(Z)$.

Table 5. Counting Result Coefficient Correlation and Regression Sub-Structure 2

\begin{tabular}{|c|c|c|c|c|c|c|}
\hline & & Corr & ons & & & \\
\hline & & $\mathrm{X} 1$ & $\mathrm{X} 2$ & X3 & $\mathrm{Y}$ & $\mathrm{Z}$ \\
\hline $\mathrm{X} 1$ & Pearson Correlation & 1 & $.976^{* *}$ & $.979^{* *}$ & $.991^{* *}$ & $.992^{* *}$ \\
\hline & Sig. (2-tailed) & & .000 & .000 & .000 & .000 \\
\hline & $\mathrm{N}$ & 122 & 122 & 122 & 122 & 122 \\
\hline $\mathrm{X} 2$ & Pearson Correlation & $.976^{* *}$ & 1 & $.948^{* *}$ & $.982^{* *}$ & $.975^{* *}$ \\
\hline & Sig. (2-tailed) & .000 & & .000 & .000 & .000 \\
\hline & $\mathrm{N}$ & 122 & 122 & 122 & 122 & 122 \\
\hline $\mathrm{X} 3$ & Pearson Correlation & $.979^{* *}$ & $.948^{* *}$ & 1 & $.978^{* *}$ & $.987^{* *}$ \\
\hline & Sig. (2-tailed) & .000 & .000 & & .000 & .000 \\
\hline & $\mathrm{N}$ & 122 & 122 & 122 & 122 & 122 \\
\hline Y & Pearson Correlation & $.991^{* *}$ & $.982^{* *}$ & $.978^{* *}$ & 1 & $.991^{* *}$ \\
\hline & Sig. (2-tailed) & .000 & .000 & .000 & & .000 \\
\hline & $\mathrm{N}$ & 122 & 122 & 122 & 122 & 122 \\
\hline $\mathrm{Z}$ & Pearson Correlation & $.992^{* *}$ & $.975^{* *}$ & $.987^{* *}$ & $.991^{* *}$ & 1 \\
\hline & Sig. (2-tailed) & .000 & .000 & .000 & .000 & \\
\hline & $\mathrm{N}$ & 122 & 122 & 122 & 122 & 122 \\
\hline
\end{tabular}

Table 6. Summary Sub-Structure 2

\begin{tabular}{|c|c|c|c|c|c|}
\hline \multicolumn{6}{|c|}{ Model Summaryb } \\
\hline Model & $\mathrm{R}$ & R Square & $\begin{array}{l}\text { Adjusted R } \\
\text { Square }\end{array}$ & $\begin{array}{l}\text { Std. Error of the } \\
\text { Estimate }\end{array}$ & Durbin-Watson \\
\hline 1 & $.996^{\mathrm{a}}$ & .992 & .992 & .36299 & 2.048 \\
\hline
\end{tabular}

a. Predictors: (Constant), Y, X3, X2, X1

b. Dependent Variable: Z

Table 7. Anova Sub-Structure 2

\begin{tabular}{|c|c|c|c|c|c|c|}
\hline \multicolumn{7}{|c|}{ ANOVA $^{b}$} \\
\hline & & Sum of Squares & $\mathrm{df}$ & Mean Square & $\mathrm{F}$ & Sig. \\
\hline \multirow[t]{3}{*}{$\frac{1}{1}$} & Regression & 1865.051 & 4 & 466.263 & 3538.598 & $.000^{\mathrm{a}}$ \\
\hline & Residual & 15.416 & 117 & .132 & & \\
\hline & Total & 1880.467 & 121 & & & \\
\hline
\end{tabular}

a. Predictors: (Constant), Y, X3, X2, X1

b. Dependent Variable: Z 
Table 8. Coefficient Sub-Structure 2 Coefficients $^{a}$

\begin{tabular}{|c|c|c|c|c|c|c|c|}
\hline \multirow[t]{2}{*}{ Model } & \multicolumn{2}{|c|}{$\begin{array}{l}\text { Unstandardized } \\
\text { Coefficients }\end{array}$} & \multirow{2}{*}{$\begin{array}{c}\begin{array}{c}\text { Standardized } \\
\text { Coefficients }\end{array} \\
\text { Beta }\end{array}$} & \multirow[b]{2}{*}{$\mathrm{T}$} & \multirow[b]{2}{*}{ Sig. } & \multicolumn{2}{|c|}{ Collinearity Statistics } \\
\hline & B & Std. Error & & & & Tolerance & VIF \\
\hline 1 (Constant) & -11.463 & 1.862 & & -6.155 & .000 & & \\
\hline $\mathrm{X} 1$ & .301 & .066 & .308 & 4.531 & .000 & 015 & 65.756 \\
\hline $\mathrm{X} 2$ & 138 & .046 & 148 & 3.030 & .003 & 029 & 34.094 \\
\hline X3 & 388 & .047 & .383 & 8.170 & .000 & .032 & 31.317 \\
\hline Y & 163 & .080 & 166 & 2.031 & .045 & .010 & 95.668 \\
\hline
\end{tabular}

a. Dependent Variable: Z

Table 5 showed that among variable in sub-structure 2 had interrelation or correlated each other. In the Table 6 could be seen that determinant coefficient $R_{\text {square }}$ or $R_{\text {yx1x2x3 }}^{2}=0,992$ $=99,2 \%$ and the effect of other variable $=1$ $0.992=0,08 \%$. Table 7 was obtained $\mathrm{F}$ value for 3723.592 with probability value Sig. $=0.000$, because Sig. $<0.05$ then Ha was accepted and Ho rejected. It means that there was significant contribution between practical activity of production unit, soft skill, on the job training, and student competence to the work radiness, thus individually test could be conducted.

\section{Individual Test of sub-structure-2}

Principle of this significance test was conducted by comparing probability value and Sig value (sig. < 0.05). Table 8 showed the result of path coefficient $\rho_{\mathrm{zx} 1}=0,308$ sig. $=0,000, \rho_{\mathrm{zx} 2}=0,148$ sig. $=0,003, \rho_{\mathrm{zx} 3}=0,383$ sig. $=0,000, \rho_{\mathrm{zy}}=0,166$ sig. $=0,045$, which means all independent variable $(\mathrm{X})$ and variable $(\mathrm{Y})$ had contribution to dependent variable $(Z)$.

\section{Discussion}

The large contribution that obtained from the result of sub-structure second test was practical activity of production unit, soft skill, and the experience of industrial work practice to the student competence and also the effect to work readiness as follow: Sub-structure 1, the large contribution of practical activity of production unit, soft skill, and the experience of industrial work practice to the student competence was obtained $\mathrm{R}^{2}$ for 0.990 . It means that practical activity of production unit, soft skill, and the experience of industrial work practice gave contribution for $99 \%$ to the student competence and the remaining $1 \%$ was affected by other factor. Sub-structure 2, the large contribution of practical activity of production unit, soft skill, the experience of industrial work practice, and student competence to the work readiness was obtained $\mathrm{R}^{2}$ for 0.992 . It means that practical activity of production unit, soft skill, the experience of industrial work practice, and student competence gave contribution for $99.2 \%$ to the work readiness and the remaining $0.08 \%$ was affected by other factor.

Program of production unit practice and industrial work practice have important role for Vocational High School, because these programs are education component that directly related to knowledge, skill, and attitude achievement which needed by student. Practical learning is learning approach based production and learning in the world of work to cope with planned competence (Hammond, 2019). Competence can be obtained through direct and indirect experience. The more direct object that learned, the more concrete they obtained competence (Sudjana \& Rivai, 2001). Production unit practice and industrial work practice are facility to obtain direct experience. Thus, by following production unit practice expected that student can obtain direct experience which support student competence. By the used competence, thus one will be able to do certain task based on knowledge, skill, and attitude. Related to student soft skill then student soft skill played role in two-third from set of competence that needed to reach success, where one-third is hard skill. Soft skill is heavily needed in student competence achievement and job seeking process and also success in career. It identifies that soft skill determines the graduates speed in getting a job. The graduates of Vocational Education must master soft skill in order to reinforce knowledge and competence in the learned field. 


\section{CONCLUSION}

As with research result and discussion that explained in the previous section, it could be concluded that: (1) There was significant contribution between practical activity of production unit, soft skill, and the experience of industrial work practice to the student Culinary Management Study Program Batam Tourism Polytechnic; (2) There was significant contribution between practical activity of production unit, soft skill, the experience of industrial work practice, and student Culinary Management Study Program Batam Tourism Polytechnic.

As with research result and conclusion that been explained, then it could be mentioned many suggestions which pointed to the School to give more improvement of existing facility and infrastructure in the production unit practice, get good cooperation with Business/Industrial World and more selective in selecting industrial work practice place for student in order to make the competence that obtained by student appropriate with what been expected by the school. The school also needed to conduct soft skill assessment that owned by student both internal and manifest to the student itself such as motivation and attitude using personality questionnaire (personal and specific) or complete personality tracking (personality inventory, set of instrument that reveal a number of character). To the next researcher, it was expected to conduct more in-depth research as follow: (1) using research subject in larger area; (2) can combine quantitative research method and qualitative research method in order to obtain more specific research result.

\section{REFERENCES}

[1] Al-Mamun, Md. Abdullah. 2012. The Soft Skill Education for the Vocational Graduate: Value as Work Readiness Skills. British Journal ef Education, Society \& Behavioural Science. Vol 2 (4): 326-338.

[2] Badan Pusat Statistik. 2018. Keadaan Ketenagakerjaan Agustus 2018. Jakarta: BPS.

[3] Badan Standar Nasional Pendidikan. 2014. Kisi-kisi Uji Kompetensi Kejuruan (UKK). Jakarta: Depdiknas.

[4] Dikmenjur. 2008. Kurikulum SMK. Jakarta: Departemen Pendidikan dan Kebudayaan.
[5] Direktorat Pembina SMK. 2007. Petunjuk Teknis Penyelenggaraan Uji Kompetensi Keahlian Sekolah Menengah Kejuruan. Jakarta.

[6] Hamalik, O. 2011. Proses Belajar Mengajar. Jakarta: PT Bumi Aksara.

[7] Hamidi. N., Ngadiman \& Muyasaroh. 2013. Locus of Control dan Prakerin dalam Kesiapan Kerja. Jurnal Pendidikan UNS, (online), 1 (1): 1-11.

[8] Hammond, Linda Darling. 2019. Implication for Educational Practice of the Science of Learning and Development. Journal Applied Developmental Science 1-44.

[9] Kawalekar, Dr (Smt) Jyoti S. 2017. The Value of Life Skill in Higher Education. IOSR Journal of Research \& Method in Education (IOSR-JRME). Vol 7, Issue 3 Ver. V, PP 43-46.

[10] Maryani, P. 2012. Kontribusi Bakat Mekanik dan Proses Belajar pada Mata Pelajaran Produktif terhadap Kompetensi serta Kesiapan untuk Bekerja di Industri. Jurnal INVOTEC, 8 (2): 167-178.

[11] Meier, Robert H \& Diane J, Atkins. 2004. Functional Restoration of Adults and children with Upper Extremity Amputation. New York: Demos Medical Publishing. Inc.

[12] Patacsil, Frederick F. et.al. 2017. Exploring the Importance of Soft and Hard Skills as Perceived by Internship Students and Industry: a Gap Analysis. Journal of Technology and Science Education (JOTSE). Vol 7(3): 347-368.

[13] Rahayu, Sutopo. 2007. Pengaruh Pengalaman dalam Praktik Industri dan Prestasi Belajar Terhadap Kesiapan Kerja Siswa Kelas XII Program Keahlian Akuntansi SMK Muhammadiyah 2 Klaten. Tesis tidak diterbitkan. Yogyakarta: UNY.

[14] Siswanto, J. 2007. Hubungan Hasil Praktik Kerja Industri (Prakerin) dan Motivasi Belajar dengan Pencapaian Kompetensi Siswa SMK Program Keahlian Teknik Mekanik Otomotif Se-Kabupaten Pasuruan. Tesis tidak diterbitkan. PPs. UM. Malang: Perpustakaan Pascasarjana Universitas Negeri Malang.

[15] Sudjana, Nana dan Ahmad Rivai. 2001. Media Pengajaran. Bandung: Sinar Baru.

[16] Utama, I. M. S. 2011. Konsep Pengembangan Panduan Evaluasi Pengembangan Soft Skill Mahasiswa melalui Proses Pembelajaran di Universitas 
Udayana. (online), (http://staff.unud.ac.id) , diakses 12 November 2014.

[17] Yanto, F. A. 2006. Ketidaksiapan Memasuki Dunia Kerja Karena Pendidikan. Jakarta: Dinamika.

[18] Zaman, S. 2012. Buku Pintar Soft Skill. Jakarta: Media Perubahan

\section{Author's Biodata}

Dyah Ayu Pradnya Paramitha, Lahir di Malang, 4 November 1988. Gelar Sarjana diperoleh tahun 2013 dan Magister diperoleh tahun 2015 di Universitas Negeri Malang. Mulai tahun 2018 tercatat sebagai mahasiswa S3 Pendidikan Teknologi dan Kejuruan di Universitas Negeri Padang. Saat ini bekerja sebagai dosen aktif di Politeknik Pariwisata Batam, di Program Studi Manajemen Kuliner mulai tahun 2017 hingga sekarang.

Krismadinata, lahir di Padang pada tanggal 11 September 1977. Lulus dengan gelar Sarjana Tenik dari Universitas Andalas pada tahun 2000. Memperoleh gelar Magister Teknik dari Institut Teknologi Bandung (ITB) pada tahun 2004, dan S3 di University Malaya Kuala Lumpur pada tahun 2012.

Nizwardi Jalinus, lahir di Palembang pada tanggal 22 Agustus 1952. Menyelesaikan program sarjana Pendidikan Teknik Mesin di Universitas Negeri Padang pada tahun 1978 dan program Doktor Pendidikan Vokasi pada tahun 1998 di University of Tasmania, Australia. Saat ini menjadi Guru besar di Fakultas Teknik Universitas Negeri Padang. 
